\title{
The Risk of HIV/AIDS in Multiple and Concurrent Sexual Relationships and Islamic Teachings
}

\author{
Amir Biglarbeigi \\ Ershad Institute of Higher Education. Iran, Islamic Republic of \\ Ismail Salami \\ University of Tehran. Iran, Islamic Republic of \\ Mohammad Amin Mozaheb \\ Imam Sadiq (A) University. Iran, Islamic Republic of \\ mozaheb.ma@gmail.com
}

\begin{abstract}
Multiple and concurrent sexual relationships are prevalent in many parts of the world and in this regard, Muslim communities are no exceptions. Islamic teachings instructing people to be faithful in sexual relationships are of paramount importance in controlling the spread of HIV through multiple and concurrent sexual relationships. However, in Islamic countries, including Iran, Muslims are allowed to have multiple and concurrent sexual partners provided that they make their sexual relationships official as temporary or permanent marriages. Adopting this approach facilitates the detection of individuals and their partners who are engaged in multiple and concurrent sexual relationships and at risk of acquiring HIV/AIDS through sexual encounters. HIV/AIDS activists in Muslim countries could use this opportunity to raise the awareness of Muslims who are involved in such relationships and lower the risk of acquiring the virus. The authors of the current study asked one of the official marriage/divorce offices based in Tehran to distribute pamphlets regarding HIV/AID testing among those who wished to register their sexual encounters within the boundaries of a temporary marriage. 80 percent of participants in this study were encouraged to do an HIV test before having any sexual encounters in temporary marriage. Taking this measure potentially reduces the increasing rate of HIV/AIDS in Muslims.
\end{abstract}

Keywords: HIV/AIDS, Marriage, Islam, Health, Iran,

\section{HIV STATUS IN THE MUSLIM COUNTRIES}

An important health issue currently affecting many individuals' lives is the HIV/AIDS epidemic. Over 25 million men and women have died of AIDS since 1981. In Africa more than 14 million AIDS orphans live (UNAIDS, 2008). In the following years, HIV/AIDS threatens more countries including the Muslim world which consists of more than 50 countries or some 2 billion people who live in different continents. In other words, "from Albania and Turkey in Europe, across countries bordering the Sahara in Northern Africa, and through the Persian Gulf and South Asia to Malaysia and Indonesia in the east, the Muslim world is home to over one and half billion people" (Kelley and Eberstadt 2005, p.5). The prevalence of HIV is relatively high in many Muslim countries. As UNAIDS (2006) reports, the rates of HIV are on a rise in many Muslim countries including Iran, Libya, and Morocco. Despite this fact, determining the exact rate of HIV-positive Muslims is extremely difficult in the case of Muslim countries, given that HIV 
statistics is not accurate and surveillance is done within a limited range in many Islamic countries (International HIV Fund, 2012).

A number of measures have been taken to curb the high incidence of HIV/AIDS in many countries. Avoiding unprotected sex, abstaining from sex, and raising public awareness of the HIV/AIDS epidemic through sex education programs are possible solutions proposed by many countries (UNAIDS, 1999). While avoidance of unprotected sex and sex education programs are effective for curbing the HIV/AIDS epidemic, in the case of Muslim communities, religious beliefs instructing people to be faithful in sexual relationships is an additional preventative measure for containing the spread of HIV through sexual encounters. In other terms, Islam prohibits a number of behaviours, including adultery, sexual intercourse outside marriage, and homosexuality for people living in the same society. Considering the above behaviours which are banned in Islam, one can regard Islamic teachings as preventive tools while looking at AIDS.

In Islam, family plays a critical role and it is the building block of society. Family in Islam "maintains protection of morals, provides emotional stability, love, kindness as well as social and economic security" (Wasi and Ahmed, 2012, p.2). It is because of these reasons that Prophet Mohammad (PBUH) has instructed that "the best Muslim is the one who is best to his family" (Wasi and Ahmed, 2012, p.2). Islam condemns pre-marital relations, but based on Islamic teaching, legitimate marriage can complete one's faith as Allah highlighted the importance of the issue in the Qur'an "Among His signs is that He has created spouses for you among yourselves so that you may dwell in tranquillity with them, and He has planted love and mercy between you; in that are signs for people who reflect" [30:21].

There are a number of verses in the Holy Qur'an with regard to condemnation of pre-marital and extra-marital relations: "Say to the believing men that they cast down their looks and guard their sexual organs; that is purer for them, surely Allah is aware of what they do. And say to the believing women that they cast down their looks and guard their sexual organs" [24:301]. "If two persons among you are guilty of lewdness, punish them both. If they repent and amend, leave them alone" [4:16]. "Nor come nigh to adultery, for it is an indecent deed and an evil way" [17:32]. Additionally, the Holy Qur'an strictly condemns homosexuality as these verses highlight the issue: "We also (sent) Lut: He said to his people 'Do ye commit lewdness such as no people in creation (ever) committed before you? For ye practice your lusts on men in preference to women: ye are indeed a people transgressing bounds'. And the answer of his people was no other than that they said: "Turn them out of your town, surely they are a people who seek to purify (themselves)" [7:80-82]. "Would ye really approach men in your lusts rather than women? Nay, you are a people who act ignorantly!" [27:55].

There are also a number of practical studies with regard to the role of Islam in preventing the HIV/AIDS in Muslim communities. According to a seminal paper by Talbott (2007), the amount of Muslim people in a country is negatively correlated to the number of people who acquire HIV/AIDS infection. The author utilized cross country regression analysis of 77 countries to analyze other correlates with HIV prevalence data which vary more than 500 -fold from .06\% in Hungary to $33.4 \%$ in Swaziland. Talbott (2007) summarized his paper in the following way "Based on cross-country linear and multiple regressions using newly gathered data from UNAIDS, the number of female commercial sex workers as a percentage of the female adult population is robustly positively correlated with countrywide HIV/AIDS prevalence levels. Confirming earlier studies, female illiteracy levels, gender illiteracy differences and income inequality within countries are also significantly positively correlated with HIV/AIDS levels. Muslims as a percentage of the population, itself highly correlated with country circumcision 
rates and previously found to be negatively correlated with HIV/AIDS prevalence, is insignificant when the percentage of commercial sex workers in a population is included in the analysis" (p.12).

In another study conducted in Harvard University by Gray (2004) it was found that "Muslim custom of circumcision could be considered as an influential factor that has something to do with less HIV/AIDS infection rate among them" (p.14). The study was carried out in 38 subSaharan African countries where the author considered religious tenets of Islam and social behaviours that may positively or negatively affect AIDS infections in those countries. He noted that Islamic teaching can be helpful in reducing the risk of HIV as having sex outside of marriage, homosexuality, as well as male circumcisions were identified as practices that help Muslims in having a reduced risk of exposure to HIV.

He went on to say that the results showed consumption of alcohol which is banned in Islam can be considered as a factor in increasing risky sexual behaviour. Furthermore, ritual washing and personal hygiene which are highly credited in Islam can reduce the risk of sexually transmitted diseases (STD) including HIV. Gray (2004) who considered carefully each Islamic tenet that can affect the rate of HIV infection concluded that "adherence to Islamic tenets seem to reduce the risk of HIV transmission."

Nevertheless, Islamic teachings allow Muslims to have multiple and concurrent sexual relationship which may increase the risk of acquiring the HIV virus in Muslim men and women. Additionally, authorities in Muslim countries oblige them to make their sexual relationships official as temporary or permanent marriages. For instance, in Iran, if the moral police catch any Muslim men and women having sexual relationships without registering their marriages, such people may be canned or incarcerated based on Iran's Sharia laws. While this procedure may be perplexing for people in the Western countries, in Islamic countries, the authorities enforce a law that says people must register their sexual history, a move which can decrease the risk of HIV/Aids. Moreover, one can take advantage of this situation in Muslim countries to empower Muslim men and women. The enforcement of marriage legalisation could help many HIV/AIDS activists and agencies to detect Muslims who are engaged in multiple and concurrent relationships and at risk for acquiring HIV/AIDS through sexual encounters. HIV/AIDS activists could approach these people with less difficulty, raise the consciousness level of the people in such relationships regarding the HIV/AIDS epidemic, and encourage them to go for regular HIV tests. While this could be a potential approach to curb the incidence of HIV among Muslims having multiple and concurrent sexual relationships, the best solution would still be to promote those religious teachings that instruct followers to be faithful in their relationships.

The number of people infected with HIV through sexual encounters is relatively high. For instance, 'in Africa - where HIV1 can still be transmitted by contaminated blood products...over 90\% of HIV1 transmission occurs during sexual intercourse' (Magezi, 2007, p.69). Thus, multiple and concurrent sexual relationships which could increase the incidence of HIV infected people through sexual encounters, as Magezi (2007) asserts, should be contained.

\section{MULTIPLE AND CONCURRENT SEXUAL RELATIONSHIPS AND ISLAM}

Religions disapprove having sexual relationships outside marriage. For instance, Christianity teaches sex before marriage is wrong... [because] sex belongs within marriage... sex is a gift of God demanding responsibility, commitment and love' (Fleming, Matthews, Smith, \& Worden Lewis, 2003, p.32). In Islam men and women are encouraged to avoid sex before marriage (Lewis \& Churchill, 2008), and sexual relationships outside marriage are not permitted under Islam (Casewit, 2007; Lewis \& Churchill, 2008; Taylor, 2005). These religious teachings can 
help to significantly reduce the spread of HIV/AIDS though sexual encounters. However, despite religious instructions, many young people are still involved in multiple and concurrent sexual relationships (Henderson, 2010).

It is important to note that Islam encourages men and women to fulfil their sexual desires only in the confines of marriage (Lewis \& Churchill, 2008). Temporary and permanent marriages are different forms of matrimony allowed in Islam. (Haeri, 1989).

In temporary marriages, the woman is only allowed to have sex with the man she is married to for a certain period of time (Sciolino, 2005). With respect to women in multiple and concurrent relationships, a female can only be married to one male at a time (Buyukcelebi, 2005). One justification for such an instruction can be the fact that, based on the latest findings on HIV, women are at higher risk of becoming infected with HIV during sexual contact as compared to their male counterparts (Quinn \& Overbaugh, 2005). As a result, the number of sexual partners for women should be limited. Such Islamic teachings could protect women against the spread of many sexually transmitted diseases, including HIV/AIDS. However, the best solution still appears to be underpinning those Islamic teachings that instruct men and women to be faithful in their sexual relationships.

The HIV/AIDS epidemic has had a significant impact on the lives of individuals, regardless of religion, gender or nationality. Sexual desires encourage many people to engage in high-risk sexual activities with multiple partners. A reliable approach to discovering whether a potential sexual partner has ever been engaged in concurrent partner relationships is to have a record of their sexual partners. As a result, following the enforcement this law, we can simply find those who are currently involved in concurrent sexual relationships. The HIV/AIDS epidemic is a multifaceted issue. An HIV test cannot detect the infection when someone has been recently exposed to the virus (San Francisco AIDS Foundation, 2010). A clear history of past sexual relationships is a more reliable source for informing us as to a person might have been infected or might be a potential candidate for being HIV positive. However, this approach does not guarantee that people engaged in multiple and concurrent sexual relationships will not acquire the HIV virus through such relationships.

We still need to promote those religious teachings that instruct followers to be faithful in their relationships or to avoid sex before marriage. Nowadays, around the world, HIV/AIDS takes the lives of many individuals on a daily basis. In the case of Muslim countries, the authors of this article believe that we should emphasise on Islamic teachings which always encourage faithfulness in sexual relationships. The following section describes more issued in this regard, paving the way for world people to live better.

\section{TEMPORARY MARRIAGES IN ISLAM}

After puberty, Muslims are recommended to marry while monitoring sexual morality in Islam. Having considered the importance of the issue (marriage as a social matter) in Islam, Bertrand Russell (2009, p.107) says, "Great religious leaders, with the exception of Prophet Mohammad (PBUH) and Confucius, if he can be called religious have in general been very indifferent to social and political considerations, and have sought rather to perfect the soul by meditation, discipline and self-denial." There are three options for a Muslim in this regard i.e., temporary abstinence, temporary marriage and permanent marriage.

Financial ability is the prerequisite of marriage; however, in some cases a Muslim does not have the ability to afford a family, hence in this situation the first option is temporary 
abstinence, as the Qur'an says "And those who cannot marry should practice restrain (or abstinence) till Allah enriches them out of His bounty." [24:33]

Practicing restrain is not possible for all Muslims, so Islam proposed another option which is temporary marriage. On the basis of Islamic laws, there are two kinds of marriage in Shiite Islam: Permanent (da'im) and temporary (munqati or mut'a). "Even according to Sunni sources, mut'a was allowed in Islam till the early days of the caliphate of 'Umar ibn al-Khattab. It was in the latter period of his rule that 'Umar declared mut'a as haram" (Rizvi, 1990, p.35).

There are some differences between permanent and temporary marriages regarding Islamic laws. In permanent marriage, there are a number of pre-defined obligations and duties for both men and women. For instance, a man is responsible for providing the necessities of life, while a woman without any medical, psychological or religious reasons, is not expected to refuse sexual relations. But in temporary marriage the story is slightly different, since both man and woman can work out their own plans and duties before marriage.

Regarding the importance of marriage in Islam, Quran says: "And among His great Signs is that He created for you mates from among yourselves so that you get tranquillity by them and $\mathrm{He}$ has put love and mercy between your (hearts); verily in that are Signs for those who reflect" [Quran 30:21]. Additionally, with regard to sexual relations, the Holy Quran says that "Successful indeed are the believers... those who abstain from sex, except with those joined to them in the marriage bond or the captives whom their right hands possess for (in their case) they are free from blame. But those who go beyond that are transgressors." [Quran 23:1-7]. Last but not least is that, in Islam polygamy and the matter of justice (in dealing with wives) are concepts which should be regarded with vigilant eyes, as Prophet Muhammad [PBUH] said, 'He, who has two wives but does not treat them equally concerning sentiment and financial affairs, will come on the Day of Resurrection handcuffed and bent over, and then he will enter into the Fire' (Reyshahri, 2008, p. 291). In simple terms, Islam says that the first and the best option is permanent marriage. Hence, by emphasizing on this Islamic teaching, we would not endanger Muslims' health.

In Islamic point of view, sexual morality plays a critical role in decreasing social problems and this sexual morality is regarded as one of the most important aspects of living in an Islamic society, hence, Islam stays against free sex. To achieve the above goal, Islam encourages all Muslims to marry after puberty while having no problem with regard to biological, physical and financial aspects.

After an in depth analysis of the different verses in the Holy Qur'an, Rizvi (1990, p. 14 ) concludes that "(a) marriage is a sign of God's power and blessings; (b) marriage is a highly recommended act of virtue which should not be avoided because of poverty; (c) sexual urge is a creative command of God placed in human nature. After equating sex with Allah's creative command, there can be no room for equating it with guilt, sin or evil".

\section{A CASE STUDY REGARDING TEMPORARY MARRIAGES IN IRAN}

In Iran, where Shiite Muslims comprise a substantial majority of the population, temporary marriages have gained substantial government support, particularly after the Islamic Revolution of 1979 (Macuch, 2006). With the advent of the Internet, a number of online dating sites have arisen which promote this type of marriage among the Iranian people. Web sites, including "2hamsan.com" and "aqdha.com" encourage many Iranian youth to legalize their 
sexual encounters through temporary marriages. This move is based on the Islamic teachings mentioned above which can shape a healthy society.

The authors of the current study asked one of the official marriage/divorce offices based in Tehran to distribute pamphlets regarding HIV/AID testing among those who came to register their sexual encounters within the boundaries of a temporary marriage. 80 percent of participants in this study were encouraged to do an HIV test before having any sexual encounters in temporary marriage. 15 percent of the participants had a sexual encounter less than three months prior to their new temporary marriage. All of these participants postponed their temporary marriage and voluntarily went for an HIV/AID test three months after the date of their sexual encounters, since they learned from the distributed pamphlets that HIV test may give false negative results during the window period. We, the authors of this article, propose that HIV activists, authorities and other nongovernmental organizations have the opportunity to inform such people regarding the danger of contracting the HIV virus when they come to register their marriages which is a must in Iran.

\section{CONCLUSION}

In conclusion, controlling the HIV/AIDS epidemic among world people, including Muslims, requires the proactive role of every individual. Religious teachings that require followers to be faithful in sexual relationships are of paramount significance. In the case of multiple and concurrent sexual relationships, Muslims are demanded to have their sexual relationships registered as temporary or permanent marriages in many Islamic countries.

It should be noted that a potential approach to curve the incidence of HIV among those having multiple and concurrent sexual relationships, would be to promote those religious teachings that instruct followers to remain faithful in sexual relationships. In the process of reducing the spread of the HIV/AIDS epidemic through sexual encounters, controlling multiple and concurrent sexual relationships requires the proactive roles of society, religion, and health agencies to reduce sexually transmitted diseases, including HIV among people. A good country where Islamic teachings have had positive impacts on people's lives is Iran. In other words, the ouster of the authoritarian regime led by Western-backed Shah Reza Pahlavi and the arrival of the Great Imam Ayatollah Khomeini from his exile in 1979 as well as the emergence of Islamic Revolution had positive impacts on the lives of Iranians (Farzaneh, 2011). Considering the mentioned issues, one can say that the Islamic teachings used as Sharia laws in Iran could help both the people and the government create a productive society where the quick spread of the HIV epidemic can be reined in.

\section{References}

Anwar, Zainah (2009, January, 4). Vulnerable housewives.

http://thestar.com.my/columnists/story.asp?col=sharingthenation\&file=/2009/1/4/columnists/sharingthena tion/2939652\&sec=Sharing+The+Nation. Accessed 12 November 2010.

Buyukcelebi, I. (2005). Living in the Shade of Islam: A Comprehensive reference of theory and practice, Somerset, NJ: The Light.

Casewit, J. F. (2007). The spiritual significance of marriage in Islam, in Voices of Islam: Voices of Life Family, Home, and Society, ed. V. Cornell, CT: Praeger.

Farzaneh, M. (2011). Iran's Islamic Revolution Creates Big Impacts, retrieved online at http://en.news.viva.co.id/news/read/204029-iran-s-islamic-revolution-creates-big-impacts

Fleming, M., Matthews, D., Smith, P., \& Worden, D. (2003). Revise for GCSE Religious Studies AQA B: Thinking about God and Morality (Revise for Religious Stds Gcse), Oxford: Heinemann Educational. 
Gray, P. B. (2004). HIV and Islam: is HIV prevalence lower among Muslims. Social Science and Medicine Journal, 58, 1751-1756.

Haeri, S. 1989. Law of desire: Temporary marriage in Shi'ite Iran (Contemporary issues in the Middle East). In Afkhami M \& Friedl E. (Eds). In the eye of the storm: Women in post-revolutionary Iran. Syracuse, NY:

Syracuse University Press.

Henderson, Frank (2010, June 9). Societal Side Effects of Contraceptive Pill.

http://www.timesofmalta.com/articles/view/20100609/letters/societal-side-effects-of-contraceptive-pill Accessed 12 September 2010.

International Development Committee. (2009). Progress on the implementation of Dfid's HIV/AIDS strategy: First report of session 2009-10, Hc 49-i, London: Stationery Office.

International HIV Fund. (2012). HIV \& the Muslim World. Retrieved from http://www.internationalhivfund.org/about-hiv-aids/hiv-the-muslim-world

Kelley, L.M. and Eberstadt, N. (2005). Behind the veil of a public health crisis: HIV/AIDS in the Muslim World, retrieved from: http://www.nbr.org/publications/specialreport/pdf/Preview/SR9_preview.pdf

Lewis, B. \& Churchill, B. E. (2008). Islam: The religion and the people, Upper Sadle River, NJ: Pearson Education.

Macuch, M. (2006). The function of temporary marriage in the context of Sasanian Family Law. In Panaino, A., \& Piras, A. (Eds.). Proceedings of the 5th Conference of the Societas Iranologica Europæa: held in Ravenna, 6-11 October 2003. Milano: Mimesis.

Magezi, V. (2007). HIV/AIDS, poverty \& pastoral care \& counseling: A home-based and congregational ministerial approach in Africa, New York City: Sun Press.

Quinn T, Overbaugh J.(2005). 'HIV/AIDS in Women: An Expanding Epidemic'. Society for Women's Health CCCVIII, no.5728, 1582-1583.

Reyshahri, M. (2008).Mizan al hikmah.Qum: Dar al-Hadith.

Rizvi, S. M. (1990). Marriage \& morals in Islam. Richmond, B.C.: Vancouver Islamic Educational Foundation.

Russell, B. (2009). Marriage and morals, New York: Liveright.

San Francisco AIDS Foundation. (2010). HIV Testing. http://www.sfaf.org/aids101/hiv_testing.html\#window. Accessed 12 January 2011

Sciolino, E. (2005). Persian mirrors: The elusive face of Iran, New York City: Free Press.

Talbott, J.R. (2007). Size matters: the number of prostitutes and the global HIV/AIDS pandemic. PLoS ONE, 2, 235-255. doi:10.1371/journal.pone.0000543

UNAIDS, (1999).Summary booklet of best practice, Geneva, Switzerland: Joint United Nations Programme on HIV/AIDS.

UNAIDS. (2006). AIDS epidemic update. UNAIDS: Geneva, Switzerland

UNAIDS (2008) .Report on the global AIDS epidemic, Geneva, Switzerland: Joint United Nations Programme on HIV/AIDS.

Wasi, A. and Ahmed, I. (2012). Islam, the Family, and HIV/AIDS. Retrieved from: http://www.ummah.com/forum/archive/index.php/t-334926.html 